Research article

\title{
Inhibition of hyaluronan export reduces collagen degradation in interleukin-1 treated cartilage
}

\author{
Barthold Deiters and Peter Prehm
}

\author{
Muenster University Hospital, Institute of Physiological Chemistry and Pathobiochemistry, Waldeyerstr. 15, D-48129 Münster, Germany \\ Corresponding author: Peter Prehm, prehm@uni-muenster.de
}

Received: 31 Jul 2007 Revisions requested: 29 Aug 2007 Revisions received: 25 Oct 2007 Accepted: 18 Jan 2008 Published: 18 Jan 2008

Arthritis Research \& Therapy 2008, 10:R8 (doi:10.1186/ar2357)

This article is online at: http://arthritis-research.com/content/10/1/R8

(C) 2008 Deiters and Prehm; licensee BioMed Central Ltd.

This is an open access article distributed under the terms of the Creative Commons Attribution License (http://creativecommons.org/licenses/by/2.0), which permits unrestricted use, distribution, and reproduction in any medium, provided the original work is properly cited.

\begin{abstract}
Background Osteoarthrosis is characterized by cartilage erosion, proteolysis of aggrecan and collagen, and disturbed rates of synthesis of aggrecan and hyaluronan by chondrocytes, with hyaluronan over-production being an early reaction. We considered that inhibition of hyaluronan export might prevent subsequent proteoglycan loss and collagen degradation.

Methods To test this hypothesis, we studied a tissue culture model using bovine cartilages explants activated with IL- $1 \alpha$ to induce osteoarthritic reactions using the phosphodiesterase- 5 inhibitors tadalafil, zaprinast and vardenafil.

Results These drugs inhibited hyaluronan export, but they did not inhibit hyaluronan synthase activity. Simultaneously, they

inhibited proteoglycan loss and collagen degradation, but not their synthesis. They also reduced the release of gelatinases into the culture media and diffusion of the indicator protein horseradish peroxidase through the cartilage explants. The mechanism of action of these compounds may be through inhibition of hyaluronan exporter multidrug resistanceassociated protein 5 (MRP5), because the effective drug concentrations were much higher than required for phosphodiesterase-5 inhibition and intracellular cGMP accumulation.

Conclusion Inhibition of hyaluronan over-production may be an appropriate target to attenuate IL-1-induced reactions in osteoarthritic cartilage.
\end{abstract}

\section{Introduction}

Destruction of joint cartilage is the major outcome of arthritic diseases such as osteoarthrosis and rheumatoid arthritis. Although chondrocytes represent only $5 \%$ of the tissue, these cells are responsible for cartilage matrix synthesis, which consists of two main components: the network of type II collagen, which provides the tensile strength and stiffness; and the large aggregating proteoglycan aggrecan, which is responsible for the osmotic swelling capability and elasticity. Aggrecan decorates a backbone of hyaluronan that is partially anchored in the plasma membrane of chondrocytes at the hyaluronan synthase site and is further bound by the cell surface receptor CD44. Aggregate formation is important from a physiological point of view because it ensures the retention of aggrecan within the collagen network.

The biosyntheses of hyaluronan and proteoglycans take place via different mechanisms and occur in different compartments
[1]. Proteoglycans are synthesized in the Golgi and exocytosed by vesicles. Hyaluronan is polymerized at the inner side of plasma membranes [1-4] and was originally thought to be exported by the synthase itself $[5,6]$, but recently the ATPbinding cassette transporter multidrug resistance protein (MRP)5 was identified as a hyaluronan exporter [7,8]. Both components aggregate in the extracellular matrix [9], with up to 200 aggrecan molecules decorating one hyaluronan chain [10]. In healthy cartilage, the hyaluronan and aggrecan are synthesized and degraded at similar rates [11], whereas the turnover of collagens is much slower [12]. The proteoglycan monomer is liberated from the hyaluronan binding region by aggrecanases, matrix metalloproteases and cathepsins [1317]. In healthy cartilage, most of hyaluronan is removed by endocytosis through the CD44 receptor [18], whereas in osteoarthritic cartilage about $90 \%$ is liberated into the environment [19]. Aggrecan leaves cartilage either as intact molecule or after proteolysis, depending on the stimulus [20].

$\mathrm{HABP}=$ hyaluronan binding protein; $\mathrm{HRPO}=$ horseradish peroxidase; $\mathrm{LL}=$ interleukin; $\mathrm{MMP}=$ matrix metalloprotease; $\mathrm{MRP}=$ multidrug resistanceassociated protein; $\mathrm{ODQ}=1 \mathrm{H}-(1,2,4)$-oxadiazolo $(4,3 \mathrm{a})$ quinoxaline-1-one. 
Key events in osteoarthritic cartilage are increased hyaluronan, decreased aggrecan synthesis [19,21], and proteolytic cleavage of collagen type II and aggrecan core protein $[22,23]$. For a long time it was believed that proteolytic degradation of collagen and aggrecan was the primary event in cartilage breakdown. Much effort to develop protease inhibitors led to compounds that were chondroprotective in vitro or in animal models [24-27], but the findings of clinical trials were equivocal $[28,29]$.

Recently, we discovered that a variety of multidrug resistance inhibitors interfered with hyaluronan export by the the multidrug resistance-associated protein MRP5 $[7,8]$. Some of the hyaluronan export inhibitors have already been applied to prevent hyaluronan over-production and proteoglycan loss in IL$1 \alpha$ activated chondrocyte cell cultures, in cartilage organ cultures and in an animal model of osteoarthrosis [30]. Because hyaluronan export by MRP5 is regulated by intracellular cGMP [8] (also an MRP5 substrate [31]), we evaluated the effects of the drugs zaprinast, vardenafil and tadalafil. These agents are structural analogues of cGMP that inhibit the cGMP-specific phosphodiesterase (PDE5) at nanomolar concentrations [32] and so they increase intracellular cGMP levels. In addition, zaprinast is also known as a MRP5 inhibitor [33]. We analyzed their effects on hyaluronan export, proteoglycan loss and collagen degradation in IL- $1 \alpha$ activated bovine articular cartilage explants.

\section{Materials and methods Materials}

Articular cartilage was obtained from the knees of 2-year-old steer provided by a local slaughterhouse. Vardenafil was from Bayer AG (Leverkusen, Germany), tadalafil was from Elli Lilly (Indianapolis, IA, USA), hyaluronan binding protein (HABP) was from Calbiochem (Schwalbach, Germany), and hyaluronan $\left(\right.$ Healon ${ }^{\circledR}$ ) was a gift from Genzyme (Cambridge, MA, USA). Polyclonal antibodies to matrix metalloprotease (MMP)9 were from Biomol (Hamburg, Germany). Additional chemicals were from Sigma-Aldrich Chemical Corporation (Taufkirchen, Germany).

\section{General methods}

The hyaluronan synthase activity was determined by incorporation of radioactive $\left[{ }^{14} \mathrm{C}\right]$ glucuronic acid from UDP$\left[{ }^{14} \mathrm{C}\right] \mathrm{GlcA}$ and UDP-GlcNac [7]. The cytotoxicity of the drugs was measured as described previously [34]. For all experiments, the weight of the explants was determined immediately after cutting to minimize evaporation and the data were related to wet weight.

\section{Determination of hyaluronan}

Cartilage explants were incubated in the absence or presence of IL-1 $(2 \mathrm{ng} / \mathrm{ml})$ and the inhibitors at various concentrations in serum-free Dulbecco's medium for 3 days. The amount of hyaluronan released into the culture medium was determined using biotinylated HABP, as described previously [30].

\section{Determination of proteoglycans}

Cartilage explants were weighed (average wet weight $20 \mathrm{mg}$ ) and incubated in the absence and presence of IL-1 $(2 \mathrm{ng} / \mathrm{ml})$ and the inhibitors at various concentrations for 5 days. The tissues were extracted with $1.5 \mathrm{ml}$ of a solution of $4 \mathrm{~mol} / \mathrm{l}$ guanidinium hydrochloride, $0.1 \mathrm{~mol} / \mathrm{l} \varepsilon$-aminohexanoid acid, 5 $\mathrm{mmol} / \mathrm{l}$ benzamidine, $10 \mathrm{mmol} / \mathrm{l} \mathrm{N}$-ethylmaleinimide and 0.5 $\mathrm{mmol} / \mathrm{l}$ phenalmethylsulfonyl fluoride for 3 days at $4^{\circ} \mathrm{C}$. The solution was centrifuged for 5 minutes at $10.000 \mathrm{~g}$ and the proteoglycans were determined in the supernatant using the alcian blue method, as described previously [35].

\section{Determination of the proteoglycan synthesis}

Chondrocytes were cultured in alginate beads, as described above, and supplemented with $25 \mu \mathrm{l}$ [35 S] sulphate $(0.5 \mathrm{mCi} /$ $\mathrm{ml}$ ) for 24 hours. The beads were washed three times with 102 $\mathrm{mmol} / \mathrm{l} \mathrm{CaCl}_{2}$ to remove un-incorporated radioactivity and dissolved in $55 \mathrm{mmol} / \mathrm{l}$ sodium citrate. Proteoglycans were isolated by the alcian blue precipitation method [36] and aliquots were used in the determination of radioactivity.

\section{Measurement of degraded collagen}

The procedure for measurement of degraded collagen is described in detail in the report by Kosaki and coworkers [37]. Cartilage explants were cultured in Dulbecco's medium for 28 days in the presence or absence of IL-1 (2 ng/ml), IL-17 (25 $\mathrm{ng} / \mathrm{ml}), 2 \mu \mathrm{mol}$ retinoic acid and hyaluronan export inhibitors, and media were changed every 2 days. The cartilage was weighed and extracted with $4 \mathrm{~mol} / \mathrm{l}$ guanidinium hydrochloride in $0.1 \mathrm{~mol} / \mathrm{l}$ Tris $\mathrm{HCl}$ ( $\mathrm{pH} 7.3$ ), $1 \mathrm{mmol} / \mathrm{l}$ lodoacetamide, 1 $\mathrm{mmol} / \mathrm{l} \mathrm{EDTA}$, and $10 \mu \mathrm{g} / \mathrm{ml}$ pepstatin A for 72 hours. The extracted explants were washed with $1 \mathrm{mmol} / \mathrm{l}$ iodoacetamide and $1 \mathrm{mmol} / /$ EDTA, and $10 \mu \mathrm{g} / \mathrm{ml}$ pepstatin in $0.1 \mathrm{~mol} / \mathrm{l}$ Tris$\mathrm{HCl}(\mathrm{pH} 7.3)$ three times for 2 hours. The denatured collagen was digested overnight at $37^{\circ} \mathrm{C}$ with a solution of $0.5 \mathrm{ml}$ of $\alpha$ chymotrypsin $(0.5 \mathrm{mg} / \mathrm{ml})$ in $1 \mathrm{mmol} / \mathrm{l}$ iodoacetamide and 1 $\mathrm{mmol} / \mathrm{l} \mathrm{EDTA}$, and $10 \mu \mathrm{g} / \mathrm{ml}$ pepstatin in $0.1 \mathrm{~mol} / \mathrm{l}$ Tris $-\mathrm{HCl}$ $(\mathrm{pH}$ 7.3). The mixture was centrifuged for 8 minutes at 10,000 $g$, and the supernatant containing the digested collagen was separated from the remaining insoluble matrix containing the intact collagen. The insoluble material was hydrolyzed with $500 \mu \mathrm{l}$ of $6 \mathrm{~mol} / \mathrm{l} \mathrm{HCl}$ at $110^{\circ} \mathrm{C}$ for 20 hours. The hydrolysate was neutralized with $500 \mu \mathrm{l}$ of $6 \mathrm{~mol} / \mathrm{l} \mathrm{NaOH}$ and undissolved material was removed by centrifugation. The amount of the collagen-specific amino acid hydroxyproline was determined. An aliquot $(25 \mu \mathrm{l})$ was mixed with $975 \mu \mathrm{l}$ citrate buffer $(57 \mathrm{~g}$ sodium acetate, $37.5 \mathrm{~g}$ sodium citrate, $5.5 \mathrm{~g}$ citric acid and $385 \mathrm{ml}$ 2-propanol in 1 I water). An aliquot $(200 \mu \mathrm{l})$ of this mixture was added to $100 \mu \mathrm{l}$ of a solution of $100 \mathrm{mg}$ chloramine $\mathrm{T}$ in $1 \mathrm{ml}$ water, $2 \mathrm{ml}$ 2-propanol and $3 \mathrm{ml}$ citrate buffer. After 20 minutes at room temperature, $100 \mu \mathrm{l}$ of $6.2 \mathrm{~mol} / / \mathrm{l}$ perchloric acid was added and reacted for 12 minutes at room 
temperature. A solution of $100 \mu$ Ehrlichs reagent $(500 \mathrm{mg}$ in $1.25 \mathrm{ml}$ ethanol and $1.25 \mathrm{ml}$ diethyleneglycol-monoethylether) was added and incubated at $60^{\circ} \mathrm{C}$ for 20 minutes. The adsorption was read at $565 \mathrm{~nm}$ and the content of hydroxyproline was calculated using 1 to $30 \mu \mathrm{g} / \mathrm{ml}$ calibration samples.

\section{Determination of collagen synthesis}

Chondrocytes were cultured in alginate beads for 1 week with $10 \%$ foetal calf serum in Dulbecco's medium. The medium was changed and supplemented with $1 \mathrm{mmol} / \mathrm{l}$ cysteine, 1 $\mathrm{mmol} / /$ pyruvate, $60 \mu \mathrm{g} / \mathrm{ml} \beta$-aminopropionitril and $25 \mu \mathrm{g} / \mathrm{ml}$ ascorbic acid, and the beads were incubated for an additional 24 hours. The medium was replaced with serum-free medium containing the above supplements, IL-1, the inhibitors and $\left[{ }^{14} \mathrm{C}\right]$ proline $(2 \mu \mathrm{Ci} / \mathrm{ml})$, and the cells were incubated for 24 hours. The beads were washed three times with $0.9 \% \mathrm{NaCl}$ and $\mathrm{CaCl}_{2}(116 \mathrm{mg} / \mathrm{l})$ for 30 minutes to remove unincorporated radioactivity, dissolved in $500 \mu$ of $55 \mathrm{mmol} / \mathrm{l}$ sodium citrate, and the radioactivity was determined.

\section{Zymography of matrix proteases}

Bovine cartilage explants were cultured in serum-free Dulbecco's medium for 5 days in the presence or absence of IL$1 \alpha(2 \mathrm{ng} / \mathrm{ml})$ and 10 or $30 \mu \mathrm{mol} / \mathrm{l}$ zaprinast, vardenafil, or tadalafil. The protein concentrations of the culture media were determined and equal amounts of proteins were directly applied to a $7.5 \%$ SDS-polyacrylamide gel that contained $0.1 \%$ gelatin. After electrophoresis, the gel was washed twice with $2.5 \%$ Triton $\mathrm{X}-100$ for 30 minutes, three times with water for 10 minutes, and incubated in a solution of $50 \mathrm{mmol} / \mathrm{l}$ Tris$\mathrm{HCl}, 5 \mathrm{mmol} / \mathrm{l} \mathrm{CaCl}, 1 \mu \mathrm{mol} / / \mathrm{ZnSO}_{4}(\mathrm{pH} \mathrm{8.0)}$ for 5 days at $37^{\circ} \mathrm{C}$. The gel was stained with Coomassie blue.

\section{Determination of protein infiltration into the cartilage matrix}

Bovine cartilage explants were cultured in Dulbecco's medium and $10 \%$ foetal calf serum in the presence or absence of IL$1 \alpha(2 \mathrm{ng} / \mathrm{ml})$ and the drugs zaprinast, tadalafil and vardenafil for 14 days. Pieces of $2 \mathrm{~mm}$ diameter and a volume of 3.15 $\mathrm{mm}^{3}$ were punched out. They were incubated in a solution of 10 units/ml of horseradish peroxidase (HRPO) in phosphatebuffered saline for 1 hour at $37^{\circ} \mathrm{C}$. The pieces were rinsed with water and shaken in $250 \mu$ phosphate-buffered saline overnight at $4^{\circ} \mathrm{C}$ to release the infiltrated enzyme. The concentrations of HRPO were determined in $50 \mu \mathrm{l}$ of the supernatants. A solution (150 $\mu$ l) of ABTS (2,2'-azino-bis [3-ethylbenzthiazoline-6-sulfonic acid]; $1 \mathrm{mg} / \mathrm{ml}$ ) and $0.03 \% \mathrm{H}_{2} \mathrm{O}_{2}$ was added, and after incubation for 30 minutes at $37^{\circ} \mathrm{C}$ the adsorbance at $405 \mathrm{~nm}$ was read.

\section{Statistical analyses}

Data are presented in the figures as mean \pm standard deviation. The $t$-test was used, and a $P$ value below 0.05 was considered statistically significant.
Figure 1
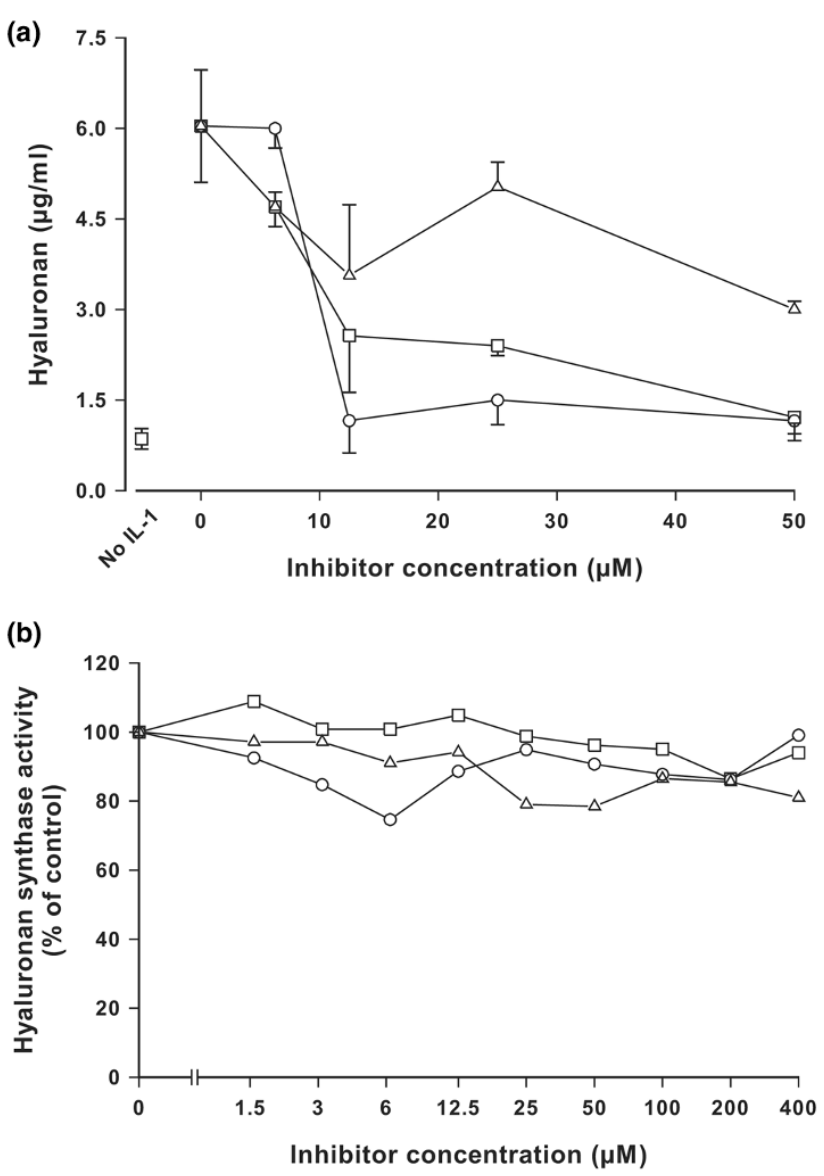

Inhibition of hyaluronan export in bovine chondrocytes. (a) Cartilage explants were incubated in the absence and presence of IL-1 $\alpha$ and the drugs tadalafil $(\bigcirc)$, zaprinast $(\square)$, or vardenafil $(\triangle)$. The concentration of hyaluronan was determined in the supernatant after 3 days. The error bars indicate the standard deviation of three determinations. (b) Effect of inhibitors on hyaluronan synthase activity. A particulate fraction of chondrocytes was prepared and incubated with the substrates UDPGlcNac and UDP-[14C]GlcA and increasing concentrations of tadalafil $(\bigcirc)$, zaprinast $(\square)$, or vardenafil $(\triangle)$, and the incorporation into $\left[{ }^{14} \mathrm{C}\right]$ hyaluronan was determined.

\section{Results \\ Inhibition of hyaluronan export}

The drugs tadalafil, zaprinast and vardenafil were analyzed for their effects on hyaluronan export from bovine cartilage explants in tissue culture. Cartilage explants were incubated for 3 days in the presence and absence of IL- $1 \alpha$ and increasing concentrations of the drugs. Figure 1 a shows that IL-1 $\alpha$ stimulated an increase in hyaluronan export by about sixfold, and the inhibitors partially reversed it. In control experiments, the inhibitors were analyzed for their effect on the hyaluronan synthase activity of chondrocytes cultured in alginate beads. Activity was reduced by less than $20 \%$ up to concentrations of $400 \mu \mathrm{mol} / \mathrm{l}$ (Figure 1b). The toxicity of the drugs was less than $10 \%$ at a concentration of $100 \mu \mathrm{mol} / /$ for the three inhibitors. 


\section{Figure 2}
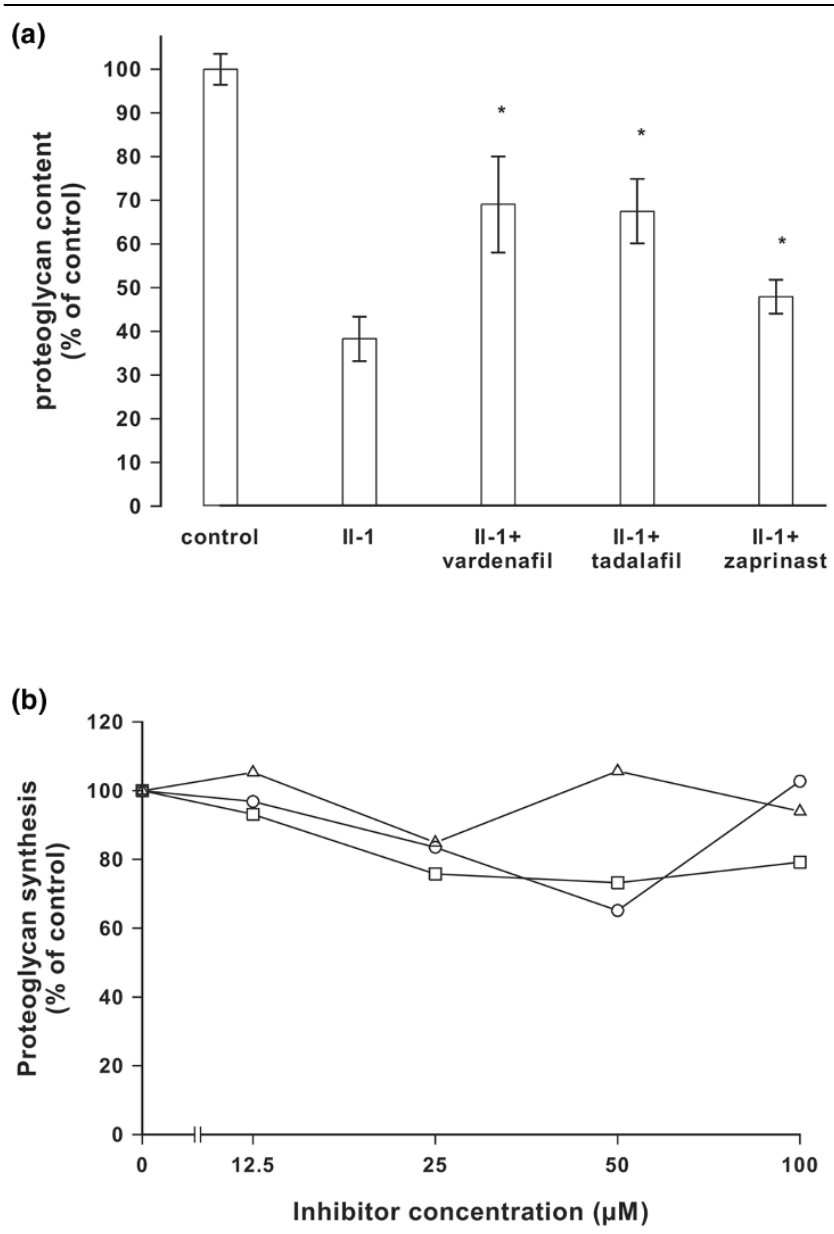

Inhibition of proteoglycan loss in bovine chondrocytes. (a) Cartilage explants were incubated in the absence and presence of IL-1 $\alpha$ and the drugs tadalafil, zaprinast, or vardenafil at concentrations of $50 \mu \mathrm{mol} / \mathrm{l}$. The tissues were weighed, extracted with guanidinium hydrochloride, and the amount of proteoglycans was determined after 5 days. The data were related to controls without IL-1 $\alpha$ as $100 \%$. The error bars represent the standard deviation of three determinations; ${ }^{*} P<0.05$. (b) Effect of inhibitor tadalafil $(\bigcirc)$, zaprinast $(\square)$, or vardenafil $(\triangle)$ on proteoglycan synthesis. Bovine chondrocytes were cultured in alginate beads and incubated with increasing concentrations of the inhibitors in the presence of $\left.{ }^{35} \mathrm{~S}\right]$ sulphate. After 24 hours the radioactivity incorporated into $\left.{ }^{35} \mathrm{~S}\right]$ proteoglycans was determined.

\section{Inhibition of proteoglycan loss}

The drugs tadalafil, zaprinast and vardenafil were analyzed for their effects on proteoglycan loss from IL- $1 \alpha$ activated bovine cartilage explants. Proteoglycans were extracted from the tissues with guanidinium hydrochloride and determined colourimetrically. Figure $2 a$ shows that $\mathrm{IL}-1 \alpha$ reduced the proteoglycan content in cartilage to less than $40 \%$ of that in the untreated control. The inhibitors protected the cartilage from proteoglycan loss. In a control experiment, the effect of the inhibitors on the proteoglycan synthesis rate was determined. Bovine chondrocytes were cultured in alginate beads and incubated with $\left.{ }^{35} \mathrm{~S}\right]$ sulphate in the presence of drugs, and inhibition of proteoglycan synthesis was found to be reduced by less than 25\% (Figure 2b). These findings confirm earlier observations obtained with other drugs [30] and suggest that zaprinast, vardenafil and tadalafil prevented proteoglycan loss from osteoarthritic cartilage primarily by inhibition of hyaluronan over-production.

\section{Inhibition of collagen degradation}

The drugs were analyzed for their effects on collagen degradation in IL- $1 \alpha$ activated cartilage explants. Preliminary experiments revealed that induction of osteoarthritic reactions by IL$1 \alpha$ was not sufficient to detect measurable amounts of collagen degradation products. Degradation can be enhanced substantially by addition of IL-17 and retinoic acid. Therefore, these activators were added. Activated cartilage explants were incubated with tadalafil, zaprinast, or vardenafil for 28 days, extracted with guanidinium hydrochloride, and digested with chymotrypsin. Degraded collagen was measured as the amount of hydroxyproline that was susceptible to chymotrypsin. Figure $3 a$ shows that cartilage activation reduced the amount of chymotrypsin-resistant collagen to $65 \%$. Inhibition of hyaluronan export restored the content of intact collagen. In a control experiment, the effect of zaprinast on collagen synthesis was measured (Figure $3 b$ ). Bovine chondrocytes were cultured in alginate beads and incubated in culture medium containing $\left[{ }^{14} \mathrm{C}\right]$ proline in the absence and presence of zaprinast and incorporation of radioactivity into pepsin-resistant collagen was determined. The total amount of collagen was not altered significantly at concentrations up to $100 \mu \mathrm{mol} / \mathrm{I}$ zaprinast. These findings suggest that the drugs did not affect collagen synthesis and that the protection from collagen degradation could involve other mechanisms.

\section{Inhibition of the action of gelatinases}

A possible explanation for the protective effect of hyaluronan export inhibition on collagen degradation could be that the altered composition and permeability of osteoarthritic cartilage allowed the diffusion of metalloproteases. It is known that chondrocytes produce gelatinases, particularly if they are activated by IL-1 [38]. We tested this possibility by measuring the release of gelatinase from IL- $1 \alpha$ activated cartilage. Cartilage explants were incubated in the absence and presence of IL-1 $\alpha$ and vardenafil, and enzymes released from the cartilage explants were analyzed by gel zymography. We also included dibutyryl-cGMP in the analysis, because cGMP has been shown to mediate IL-1 signalling in chondrocytes [39]. Figure $4 \mathrm{a}$ shows three bands with molecular weights of $86 \mathrm{kDa}, 66$ $\mathrm{kDa}$ and $62 \mathrm{kDa}$. The upper band was probably pro-MMP9, because it reacted with monoclonal antibodies in Western blots (data not shown). The lower two bands comigrated with an authentic sample of pro-MMP2 and MMP2 gelatinases (from Dr R Dreier; data not shown). IL-1 $\alpha$ enhanced the release of the gelatinases, and this release was not significantly altered by addition of dibutyryl-cGMP. Vardenafil reduced the gelatinase release in a concentration-dependent 
Figure 3

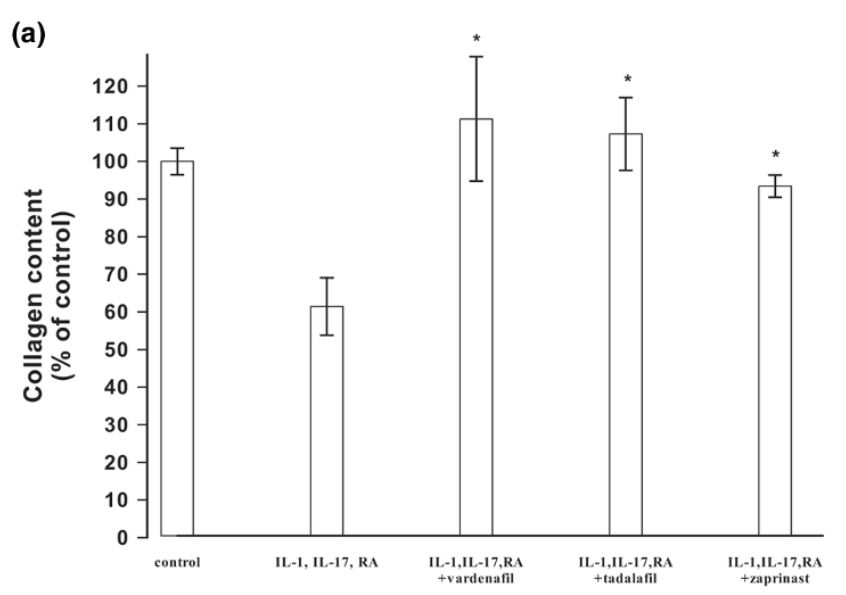

(b)

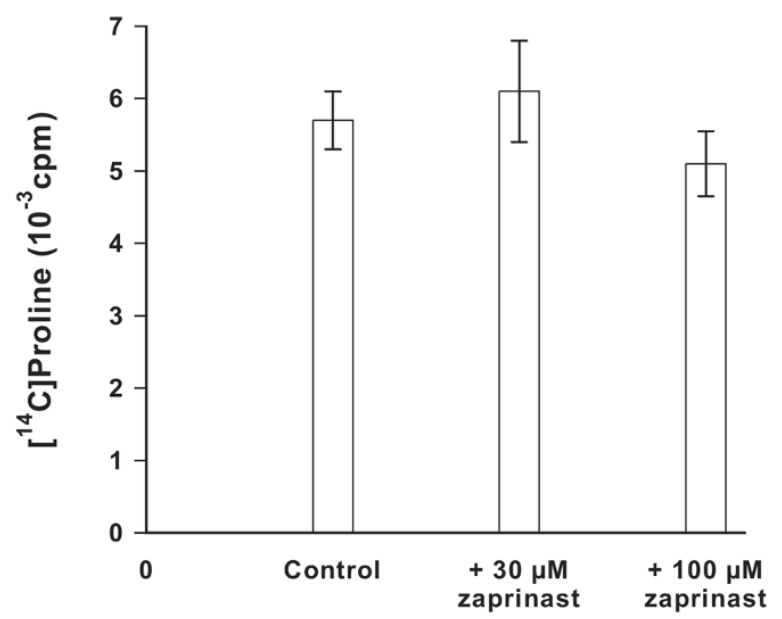

Quantitative analysis of collagen degradation and its inhibition. (a) Cartilage explants were incubated with IL-1 $\alpha, \mathrm{IL}-17$ and retinoic acid in the absence or presence of zaprinast, tadalafil, or vardenafil at concentrations of $50 \mu \mathrm{mol} / / \mathrm{l}$ for 4 weeks at $37^{\circ} \mathrm{C}$. The amount of chymotrypsinresistant collagen was determined as hydroxyproline. The values were related to the control that contained $23 \mu \mathrm{g}$ hydroxyproline/mg cartilage as $100 \%$. The bars indicate the standard deviation of four determinations; ${ }^{\star} P<0.05$. (b) Bovine chondrocytes were grown in alginate beads and and collagen was labeled by incorporation of $\left[{ }^{14} \mathrm{C}\right]$ proline in the absence or presence of $30 \mu \mathrm{mol} / /$ and $100 \mu \mathrm{mol} / / \mathrm{l}$ zaprinast. The amount of $\left[{ }^{14} \mathrm{C}\right]$ collagen within the alginate beads was determined after 24 hours. The bars indicate the standard deviation of four determinations.

manner. Similar results were obtained with zaprinast and tadalafil (data not shown).

In a control experiment, we analyzed whether inhibition of hyaluronan export altered the syntheses of gelatinases by chondrocytes in unstimulated cartilage explants. The explants were incubated in the absence and presence of $100 \mu \mathrm{mol} / /$ zaprinast, vardenafil and tadalafil, respectively, and the gelati-
Figure 4

(a)

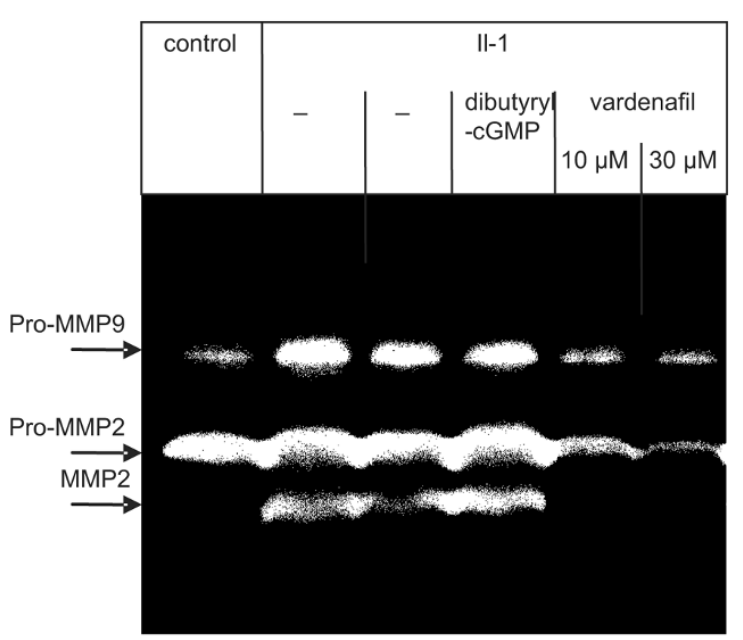

(b)

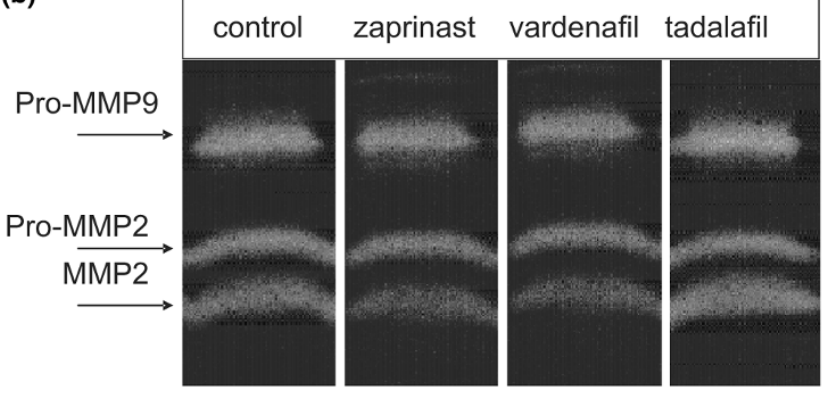

Effect on gelatinases. (a) Inhibition of gelatinase liberation from bovine cartilage explants. Cartilage explants were incubated in the absence or presence of IL- $1 \alpha$ and $25 \mu \mathrm{mol} / /$ dibutyryl-cGMP or $10 \mu \mathrm{mol} / \mathrm{l}$ or 30 $\mu \mathrm{mol} / \mathrm{l}$ vardenafil for 4 days at $37^{\circ} \mathrm{C}$. The lanes marked with (-) indicate two independent control experiments with IL-1 only. The activity of gelatin-degrading enzymes released into the culture supernatant was determined by zymography. (b) Unaffected gelatinase synthesis.

Unstimulated explants were incubated for 10 days in the absence and presence of $100 \mu \mathrm{mol} / \mathrm{l}$ zaprinast, vardenafil and tadalafil, and the gelatinase activities were again analyzed by gel zymography. MMP, matrix metalloprotease.

nase activities were again analyzed by gel zymography. Figure $4 \mathrm{~b}$ shows no differences in enzyme activities between the samples. These results showed that inhibition of hyaluronan export in IL-1 activated cartilage explants inhibited the release of gelatinases into the culture medium.

Inhibition of protein diffusion through cartilage explants If the altered composition of arthritic cartilage with increased hyaluronan and decreased proteoglycan content was responsible for facilitated diffusion of degrading enzyme through the matrix, exogenous enzymes should infiltrate better. This hypothesis was tested using HRPO as an indicator protein. Cartilage explants were incubated in the absence or presence of IL- $1 \alpha$ and zaprinast, vardenafil, or tadalafil in increasing concentrations. The explants were incubated with the indicator protein HRPO to allow diffusion into the cartilage. After 


\section{Figure 5}
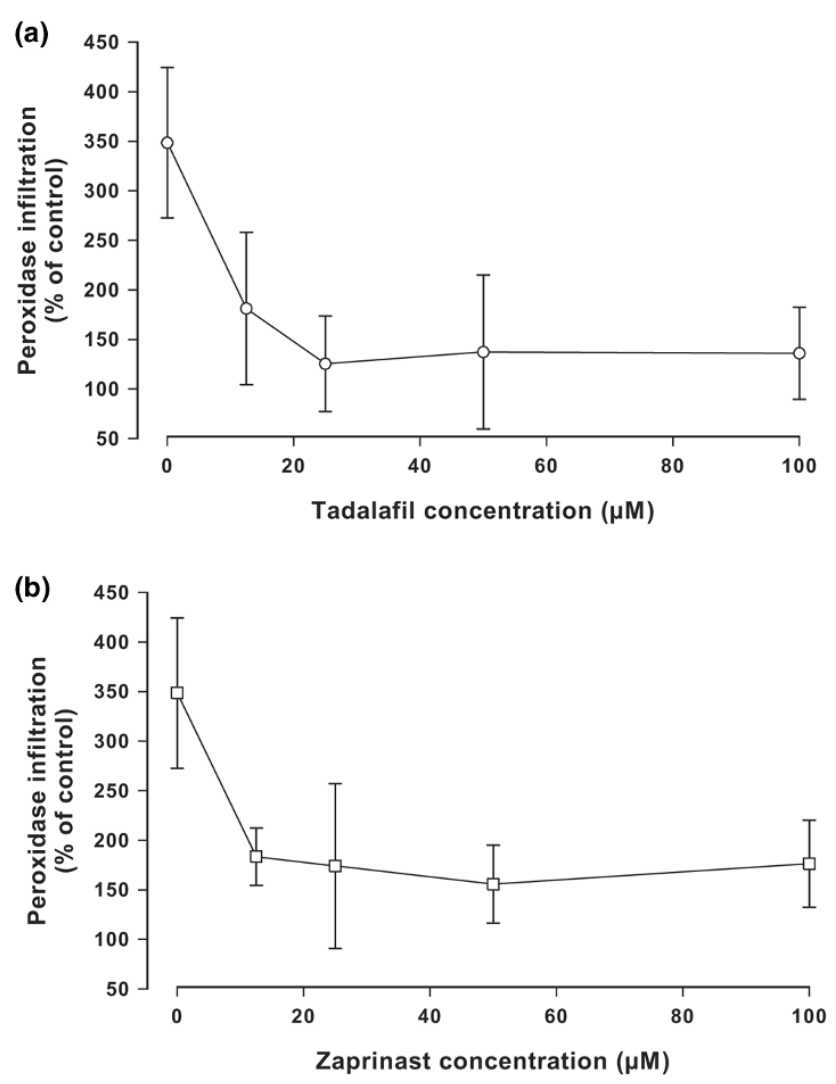

(c)

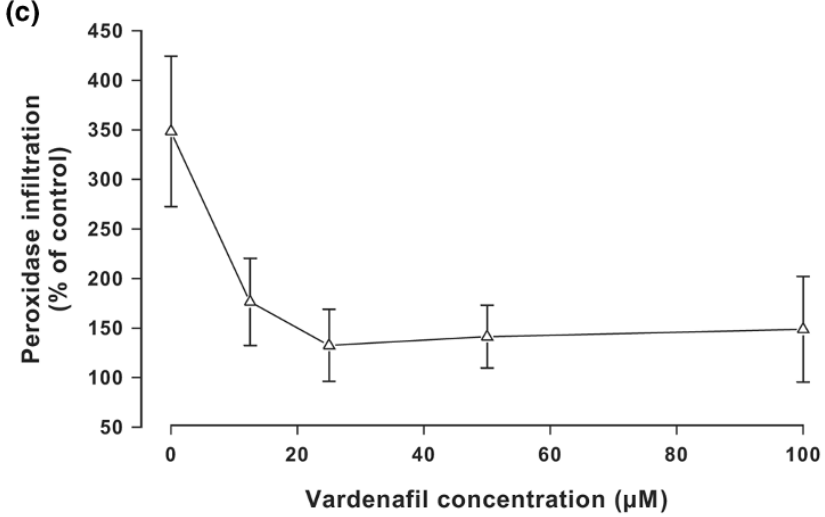

Inhibition of protein infiltration into bovine cartilage explants. Cartilage explants were incubated in the absence or presence of IL-1 $\alpha$ and (a) tadalafil, (b) zaprinast, or (c) vardenafil for 14 days at $37^{\circ} \mathrm{C}$. The

explants were then incubated with horseradish peroxidase as indicator protein for 1 hour. After washing, the amount of enzyme that had infiltrated the explants was determined by a colour reaction. The error bars represent the standard deviation of eight determinations.

extensive washing, the explants were further incubated in phosphate-buffered saline to liberate the infiltrated enzyme. The amount of liberated enzyme was determined by a colour reaction. Control experiments indicated that the drugs did not have any direct effect on the peroxidase activity at micromolar concentrations. Figure 5 shows that IL- $1 \alpha$ treatment led to an increase of enzyme infiltration of about $350 \%$ over the unstimulated control (100\%). Inhibition of hyaluronan export reduced the IL-1 $\alpha$ induced enzyme infiltration almost to control values.

\section{Mechanism of inhibitor action}

There are two possible mechanisms for the inhibitory action of the drugs zaprinast, vardenafil and tadalafil. Because of their PDE5 inhibitory activity, with Ki values of $300 \mathrm{nmol} / \mathrm{l}$ for zaprinast, $1.5 \mathrm{nmol} / \mathrm{l}$ for vardenafil and $2.9 \mathrm{nmol} / \mathrm{l}$ for tadalafil $[40,41]$, they will certainly raise the concentration of intracellular cGMP that could inhibit hyaluronan export by MRP5 [8]. It is also possible that they additionally act as MRP5 inhibitors, because they are structural analogues of cGMP; also, it is known that zaprinast inhibits transport at concentrations between $20 \mathrm{nmol} / \mathrm{l}$ and $250 \mu \mathrm{mol} / \mathrm{l}$, depending on the transported substrate $[33,42,43]$. If the drugs acted only through inhibition of PDE5, then also other unrelated PDE5 inhibitors or addition of other cGMP analogs should have similar effects. We therefore analyzed hyaluronan export, proteoglycan loss and collagen degradation of $\mathrm{IL}-1$ activated cartilage explants in the presence of dibutyryl-cGMP and ODQ $(1 \mathrm{H}-[1,2,4]$-oxadiazolo [4,3a]quinoxaline-1-one), which is a selective inhibitor of the soluble nitric oxide inducible guanylate cyclase. Figure 6 shows that none of the parameters was significantly altered by these treatments. Similar results were obtained with bromocGMP (data not shown). These findings suggest that alterations of the intracellular cGMP concentration did not account

Figure 6

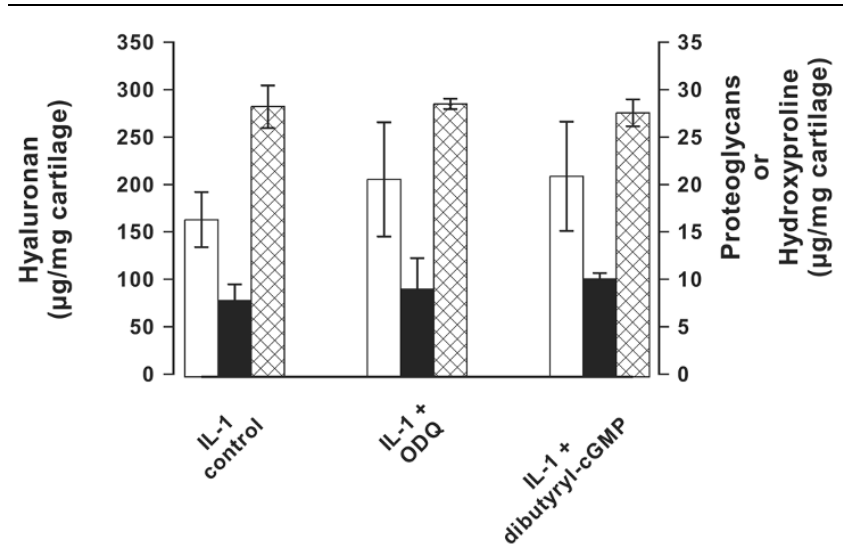

Influence of cGMP modulators. Shown is the influence of cGMP modulators on the hyaluronan (open bars), proteoglycan (solid bars), and collagen (cross-hatched bars) production of bovine cartilage. Cartilage explants were cultured in the presence of $2 \mathrm{ng} / \mathrm{ml} \mathrm{IL-1}$ and the guanylate cyclase inhibitor ODQ $(1 \mathrm{H}-[1,2,4]$-oxadiazolo [4,3a]quinoxaline-1one; $25 \mu \mathrm{mol} / \mathrm{l})$ or dibutyryl-cGMP $(25 \mu \mathrm{mol} / \mathrm{l})$. The incubation periods were for 3 days for hyaluronan, 5 days for proteoglycans and 28 days for collagens. For stimulation of collagen degradation, the cartilage explants were supplemented with $25 \mathrm{ng} / \mathrm{ml} \mathrm{IL-17}$, and $2 \mu \mathrm{mol} / \mathrm{l}$ retinoic acid. The concentrations of hyaluronan in the supernatant, proteoglycans and collagen (as hydroxyproline) were determined as described under Materials and methods. The error bars represent the standard deviation of three determinations. 
for the inhibitory effects of the drugs zaprinast, vardenafil and tadalafil.

\section{Discussion}

One of the earliest events in the pathogenesis of osteoarthritis is hyaluronan over-production of chondrocytes that precedes the stimulation of protease synthesis, collagen degradation and cartilage destruction [44-46]. It can be induced by IL-1 treatment in cell and organ culture and in animal models of osteoarthritis. IL-1 alters the cartilage composition by influencing the transcription rate of enzymes and matrix components [47].

In a previous report we showed that hyaluronan over-production led to loss of proteoglycans from osteoarthritic cartilage [30]. Inhibition of hyaluronan over-production normalized the proteoglycan content on alginate cultures of bovine chondrocytes, in cartilage explants and in an animal model of osteoarthrosis. We showed that enhanced intracellular cGMP levels reduce hyaluronan export from fibroblasts [8]. In the present study we extended the effect of hyaluronan export inhibitors to collagen degradation. We used the drugs zaprinast, vardenafil and tadalafil that were originally developed as PDE5 inhibitors [32].

We showed here that the drugs inhibited hyaluronan export, and protected cartilage from proteoglycan loss, release of metalloproteases into the medium and collagen degradation. The drugs did not influence substantially the rates of synthesis of hyaluronan, proteoglycans, metalloproteases and collagens. Our experiments also suggest a mechanism for how the inhibitors of hyaluronan export were able to prevent collagen degradation. Hyaluronan over-production increased the infiltration of the indicator protein HRPO into IL- $1 \alpha$ treated cartilage, and this infiltration was reduced by inhibition of hyaluronan export. It is likely that this inhibition also applies to reduced diffusion of proteoglycans and gelatinases MMP2 and MMP9 or other degrading enzymes out of the cartilage or from their origin to the targets within the cartilage.

The reason for the enhanced diffusion of proteins through osteoarthritic cartilage can be found in the altered cartilage composition. Proteoglycans at high concentrations in cartilage play a critical role in the flow and diffusion of macromolecules. Because of the high density of fixed charges, they vigorously restrict diffusion $[48,49]$. If the dense packing of proteoglycans is lost and replaced by voluminous hyaluronan, degrading enzymes can freely reach their targets. It has indeed been demonstrated that aggrecan protects cartilage collagen from proteolytic degradation [50]. As a consequence of this scenario, collagen is protected from degradation by inhibition of hyaluronan export.

We also analyzed the mechanism of hyaluronan export inhibition. At nanomolar concentrations, the PDE5 inhibitors sub- stantially elevate the intracellular cGMP levels [32]. Zaprinast acts also as a MRP5 inhibitor in micromolar concentrations [33]. Because the effects that we observed on hyaluronan export, proteoglycan loss and collagen degradation were all found in the micromolar range, it is likely that the drugs primarily exerted their effects on export by MRP5 rather than through an increase in intracellular cGMP levels. Although based on a limited dataset, the rank order of potency for PDE5 inhibition of zaprinast $(\mathrm{Ki}=300 \mathrm{nmol} / \mathrm{l})$, tadalafil $(\mathrm{Ki}=2.9$ $\mathrm{nmol} / \mathrm{l})$ and vardenafil $(\mathrm{Ki}=1.5 \mathrm{nmol} / \mathrm{l})$ does not correlate with the apparent potency of these compounds in inhibiting hyaluronan export induced by IL-1 (Figure 1). This notion was supported by our experiments that altered the intracellular cGMP by the specific guanylate cyclase inhibitor ODQ and the analogues dibutyryl-cGMP and bromo-cGMP. These compounds did not have any significant effect on hyaluronan export, proteoglycan loss and collagen degradation. The lack of an effect by cGMP analogues on chondrocytes is surprising and clearly different from the effects on fibroblasts [8]. Such cell-dependent discrepancies of MRP5 inhibition were previously observed in other cell lines and are probably due to different MRP5 copy numbers per cell [43].

The drugs zaprinast, tadalafil and vardenafil have been developed for other disturbances and are certainly not ideal for treatment of osteoarthrosis. It may be worthwhile to develop specific hyaluronan export inhibitors, because they could not only prevent proteoglycan loss and collagen degradation, but also inhibit subsequent reactions that lead to apoptosis of chondrocytes.

\section{Conclusion}

Inhibition of hyaluronan export from chondrocytes attenuated proteoglycan loss, collagen degradation, protein diffusion and metalloprotease activity in IL-1 activated cartilage and could be effective in osteoarthrosis.

\section{Competing interests}

The authors declare that they have no competing interests.

\section{Authors' contributions}

BD performed the experiments, evaluated the data and designed the experiments. PP evaluated the data, designed experiments and wrote the manuscript.

\section{Acknowledgements}

The authors thank Professors P Bruckner and JE Scott for their critical review of the manuscript, and U Rasmussen and R Schulz for technical assistance. This work was supported by the Deutsche Forschungsgemeinschaft (SFB 492).

\section{References}

1. Prehm P: Hyaluronate is synthesized at plasma membranes. Biochem J 1984, 220:597-600.

2. Prehm P: Synthesis of hyaluronate in differentiated teratocarcinoma cells. Mechanism of chain growth. Biochem J 1983, 211:191-198. 
3. Prehm P: Synthesis of hyaluronate in differentiated teratocarcinoma cells. Characterization of the synthase. Biochem J 1983, 211:181-189.

4. Prehm P: Biosynthesis of hyaluronan: direction of chain elongation. Biochem J 2006, 398:469-473.

5. Tlapak-Simmons VL, Kempner ES, Baggenstoss BA, Weigel PH: The active streptococcal hyaluronan synthases (HASs) contain a single HAS monomer and multiple cardiolipin molecules. J Biol Chem 1998, 273:26100-26109.

6. Pummill PE, Kempner ES, DeAngelis PL: Functional molecular mass of a vertebrate hyaluronan synthase as determined by radiation inactivation analysis. J Biol Chem 2001, 276:39832-39835.

7. Prehm P, Schumacher U: Inhibition of hyaluronan export from human fibroblasts by inhibitors of multidrug resistance transporters. Biochem Pharmacol 2004, 68:1401-1410.

8. Schulz T, Schumacher U, Prehm P: Hyaluronan export by the abc-transporter mrp5 and its modulation by intracellular cGMP. J Biol Chem 2007, 282:20999-21004.

9. Prehm P: Mechanism, localization, and inhibition of hyaluronate synthesis. In Articular cartilage biochemistry Edited by: Kuettner K. New York, NY: Raven Press; 1986:81-91.

10. Tang LH, Buckwalter JA, Rosenberg LC: Effect of link protein concentration on articular cartilage proteoglycan aggregation. $J$ Orthop Res 1996, 14:334-339.

11. Morales TI, Hascall VC: Correlated metabolism of proteoglycans and hyaluronic acid in bovine cartilage organ cultures. $J$ Biol Chem 1988, 263:3632-3638.

12. Maroudas A, Palla G, Gilav E: Racemization of aspartic acid in human articular cartilage. Connect Tissue Res 1992, 28:161-169.

13. Sugimoto $K$, lizawa $T$, Harada $H$, Yamada $K$, Katsumata $M$, Takahashi M: Cartilage degradation independent of MMP/aggrecanases. Osteoarthritis Cartilage 2004, 12:1006-1014

14. Arner EC: Aggrecanase-mediated cartilage degradation. Curr Opin Pharmacol 2002, 2:322-329.

15. Smith GN Jr: The role of collagenolytic matrix metalloproteinases in the loss of articular cartilage in osteoarthritis. Front Biosci 2006, 11:3081-3095.

16. Salminen-Mankonen HJ, Morko J, Vuorio E: Role of cathepsin K in normal joints and in the development of arthritis. Curr Drug Targets 2007, 8:315-323.

17. Embry JJ, Knudson W: G1 domain of aggrecan cointernalizes with hyaluronan via a CD44-mediated mechanism in bovine articular chondrocytes. Arthritis Rheum 2003, 48:3431-3441.

18. Hua $\mathrm{Q}$, Knudson $\mathrm{CB}$, Knudson $\mathrm{W}$ : Internalization of hyaluronan by chondrocytes occurs via receptor-mediated endocytosis. J Cell Sci 1993, 106:365-375.

19. D'Souza AL, Masuda K, Otten LM, Nishida Y, Knudson W, Thonar EJ: Differential effects of interleukin-1 on hyaluronan and proteoglycan metabolism in two compartments of the matrix formed by articular chondrocytes maintained in alginate. Arch Biochem Biophys 2000, 374:59-65.

20. Sztrolovics R, White RJ, Roughley PJ, Mort JS: The mechanism of aggrecan release from cartilage differs with tissue origin and the agent used to stimulate catabolism. Biochem J 2002, 362:465-472.

21. Nishida Y, D'Souza AL, Thonar EJ, Knudson W: Stimulation of hyaluronan metabolism by interleukin-1alpha in human articular cartilage. Arthritis Rheum 2000, 43:1315-1326.

22. Smith RL: Degradative enzymes in osteoarthritis. Front Biosci 1999, 4:D704-D712.

23. Poole AR, Nelson F, Dahlberg L, Tchetina E, Kobayashi M, Yasuda T, Laverty S, Squires G, Kojima T, Wu W, Billinghurst RC: Proteolysis of the collagen fibril in osteoarthritis. Biochem Soc Symp 2003, 70:115-123.

24. Bottomley KM, Borkakoti N, Bradshaw D, Brown PA, Broadhurst MJ, Budd JM, Elliott L, Eyers P, Hallam TJ, Handa BK, Hill CH, James M, Lahm HW, Lawton G, Merritt JE, Nixon JS, Röthlisberger $\mathrm{U}$, Whittle A, Johnson $\mathrm{WH}$ : Inhibition of bovine nasal cartilage degradation by selective matrix metalloproteinase inhibitors. Biochem J 1997, 323:483-488.

25. Caputo CB, Sygowski LA, Wolanin DJ, Patton SP, Caccese RG, Shaw A, Roberts RA, DiPasquale G: Effect of synthetic metalloprotease inhibitors on cartilage autolysis in vitro. J Pharmacol Exp Ther 1987, 240:460-465.
26. Cawston T, Plumpton T, Curry V, Ellis A, Powell L: Role of TIMP and MMP inhibition in preventing connective tissue breakdown. Ann N Y Acad Sci 1994, 732:75-83.

27. Seed MP, Thomson TA, Gardner CR: Investigation of the role of metalloproteinases in recombinant human interleukin-1 betainduced degradation of rat femoral head cartilage. Drugs Exp Clin Res 1991, 17:355-361.

28. Greenwald RA: Thirty-six years in the clinic without an MMP inhibitor. What hath collagenase wrought? Ann N Y Acad Sci 1999, 878:413-419.

29. Elliott $S$, Cawston T: The clinical potential of matrix metalloproteinase inhibitors in the rheumatic disorders. Drugs Aging 2001, 18:87-99.

30. Prehm P: Inhibitors of hyaluronan export prevent proteoglycan loss from osteoarthritic cartilage. J Rheumatol 2005 32:690-696.

31. Andric SA, Kostic TS, Stojilkovic SS: Contribution of multidrug resistance protein MRP5 in control of cGMP intracellular signaling in anterior pituitary cells. Endocrinology 2006, 147:3435-3445.

32. Kulkarni SK, Patil CS: Phosphodiesterase 5 enzyme and its inhibitors: update on pharmacological and therapeutical aspects. Methods Find Exp Clin Pharmacol 2004, 26:789-799.

33. Pratt S, Shepard RL, Kandasamy RA, Johnston PA, Perry W III, Dantzig AH: The multidrug resistance protein 5 (ABCC5) confers resistance to 5 -fluorouracil and transports its monophosphorylated metabolites. Mol Cancer Ther 2005, 4:855-863.

34. O'Brien J, Wilson I, Orton T, Pognan F: Investigation of the alamar blue (resazurin) fluorescent dye for the assessment of mammalian cell cytotoxicity. Eur J Biochem 2000 267:5421-5426.

35. Bjornsson S: Simultaneous preparation and quantitation of proteoglycans by precipitation with alcian blue. Anal Biochem 1993, 210:282-291.

36. Terry DE, Chopra RK, Ovenden J, Anastassiades TP: Differential use of alcian blue and toluidine blue dyes for the quantification and isolation of anionic glycoconjugates from cell cultures: application to proteoglycans and a high-molecular-weight glycoprotein synthesized by articular chondrocytes. Anal Biochem 2000, 285:211-219.

37. Kosaki R, Watanabe K, Yamaguchi Y: Overproduction of hyaluronan by expression of the hyaluronan synthase Has2 enhances anchorage-independent growth and tumorigenicity. Cancer Res 1999, 59:1141-1145.

38. Sasaki K, Hattori T, Fujisawa T, Takahashi K, Inoue H, Takigawa M: Nitric oxide mediates interleukin-1-induced gene expression of matrix metalloproteinases and basic fibroblast growth factor in cultured rabbit articular chondrocytes. J Biochem (Tokyo) 1998, 123:431-439.

39. Geng Y, Zhou L, Thompson WJ, Lotz M: Cyclic GMP and cGMPbinding phosphodiesterase are required for interleukin-1induced nitric oxide synthesis in human articular chondrocytes. J Biol Chem 1998, 273:27484-27491.

40. Turko IV, Francis SH, Corbin JD: Potential roles of conserved amino acids in the catalytic domain of the cGMP-binding cGMP-specific phosphodiesterase. J Biol Chem 1998, 273:6460-6466.

41. Blount MA, Zoraghi $\mathrm{R}, \mathrm{Ke} \mathrm{H}$, Bessay EP, Corbin JD, Francis SH: A 46-amino acid segment in phosphodiesterase-5 GAF-B domain provides for high vardenafil potency over sildenafil and tadalafil and is involved in phosphodiesterase-5 dimerization. Mol Pharmacol 2006, 70:1822-1831.

42. Sundkvist E, Jaeger R, Sager G: Pharmacological characterization of the ATP-dependent low $\mathrm{K}(\mathrm{m})$ guanosine $3^{\prime}, 5^{\prime}$-cyclic monophosphate (cGMP) transporter in human erythrocytes. Biochem Pharmacol 2002, 63:945-949.

43. Borst $P$, de WC, van de WK: Multidrug resistance-associated proteins 3, 4, and 5. Pflugers Arch 2006, 453:661-673.

44. Kozaci LD, Buttle DJ, Hollander AP: Degradation of type II collagen, but not proteoglycan, correlates with matrix metalloproteinase activity in cartilage explant cultures. Arthritis Rheum 1997, 40:164-174.

45. Billinghurst RC, Wu W, lonescu M, Reiner A, Dahlberg L, Chen J, van Wart $H$, Poole AR: Comparison of the degradation of type II collagen and proteoglycan in nasal and articular cartilages induced by interleukin-1 and the selective inhibition of type II 
collagen cleavage by collagenase. Arthritis Rheum 2000, 43:664-672.

46. Bayliss MT, Howat S, Davidson C, Dudhia J: The organization of aggrecan in human articular cartilage. Evidence for agerelated changes in the rate of aggregation of newly synthesized molecules. J Biol Chem 2000, 275:6321-6327.

47. Aigner T, Soeder S, Haag J: IL-1 beta and BMPs - interactive players of cartilage matrix degradation and regeneration. Eur Cell Mater 2006, 12:49-56.

48. Maroudas A: Biophysical chemistry of cartilaginous tissues with special reference to solute and fluid transport. Biorheology 1975, 12:233-248.

49. Maroudas A, Scheiderman R, Popper O: The role of water, proteoglycan, and collagen in solute transport in cartilage. In Articular Cartilage and Osteoarthritis Edited by: Kuettner K, Schleyerbach R, Peyron JG, Hascall VC. New York, NY: Raven Press; 1992:355-371.

50. Pratta MA, Yao W, Decicco C, Tortorella MD, Liu RQ, Copeland RA, Magolda R, Newton RC, Trzaskos JM, Arner EC: Aggrecan protects cartilage collagen from proteolytic cleavage. J Biol Chem 2003, 278:45539-45545. 